\title{
STUDENTS MARRIAGE READINESS BASED ON CULTURAL BACKGROUND
}

\author{
Ninil Elfira ${ }^{1}$
}

\begin{abstract}
This study is an attempt to describe the cultural factors in marital readiness. Marital readiness is an important point in creating happiness in domestic life. This research tries to reveal the marital readiness of students based on cultural background. The study was conducted by using the scale of marital readiness instrument, on 57 students with Minangkabau cultural background and Malay culture with data analysis using one-way Anova. The results of the analysis illustrate that there are significant differences in marital readiness between students with Minangkabau cultural background and Malay culture. Where Minangkabau superior to Malay culture. So that the need for training or intervention to be able to develop marital readiness.
\end{abstract}

Keywords: Marital readiness, culture

JOMSIGN: Journal of Multicultural Studies in Guidance and Counseling

Website: http://ejournal.upi.edu/index.php/JOMSIGN

Permalink: http://ejournal.upi.edu/index.php/JOMSIGN/article/view/6314

How to cite (APA): Elfira, N. (2018). Student's Marriage Readiness Based on Cultural Background. JOMSIGN: Journal of Multicultural Studies in Guidance and Counseling, 2(2), 126-133

This is an open-access article distributed under the terms of the Creative Commons Attribution 4.0 International License, which permits unrestricted use, distribution, and reproduction in any medium, provided the original work is properly cited.

\section{INTRODUCTION}

Marriage readiness does not get much attention in the world of research so that the literature becomes little (Larson, 1988; Miller, Schvaneveldt \& Jenson, 1981). Marriage readiness is an expression used to show the preparation of what each person must do before they are ready to get married, not only that but also what individuals believe that makes them ready to get married (Gunnels, 2013; Carroll et al., 2008 ). Stinnett (1969) believes that marriage readiness is related to marital competence while Larson (1988) defines readiness for marriage as a subjective evaluation of one's readiness to carry out responsibilities and challenges in marriage.

Preparing for marriage helps individuals to learn how each partner (Williams, Riley, \& Dyke, 2010). So some experts tried to formulate the

${ }^{1}$ STIT Ahlussunnah Bukittinggi; Amuraalfi0307@gmail.com 
instrument. The use of instruments is one way to see the level of readiness of individual marriages so that they can help in developing their readiness to get married. One of the model instruments used in the United States is the Premarital Assessment Questionnaires, this instrument is given to couples to see how pastors provide premarital education, an empirical approach is also used to see how marriage preparation (Williams et al., 2010; Wilmoth \& Smyser, nd).

Stinnett (1969) formulated The Readiness for Marital Competence Index (RMCI), to see what contributed to the level of readiness for marriage. This research conducted in 1969 was considered to be no longer relevant to current conditions let alone the changing trends in the United States such as postponing marriage, prioritizing education and premarital sex (Badger \& Badger, 2005).

Larson (1988) saw the perception of young people in the US about the readiness to get married, using Stinnett's RMCI which had been revised according to their needs. This research may still be continued by looking at how personal characteristics of individuals, such as attitudes about marriage and experiences about marriage readiness (Holman \& Li, 1997).

Subsequent research was carried out by Holman \& Li (1997) with the development of a theoretical model between the relationships of premarital factors (ie, the process of partner interaction, background characteristics, individual traits and attitudes, and significant other people's approval) with perceived readiness for marriage. This study uses the Preparation for Marriage (PREP-M) Questionnaire. Holman and Li also used The Readiness For Marriage Subscale so that marriage readiness variables became more specific (ie, emotional, financial, and sexual) and those that have been successfully used in other studies, such as Larson (Larson \& Thayne, nd) study marriage readiness for adults young alcoholic.

Larson (Larson \& Thayne, n.d.) replicates the Holman and Li method (1997) using The Readiness for Marriage Subscale of the PREP-M Instrument. They found that young adult alcoholics consider themselves less ready to get married and also want to wait significantly longer to get married than nonalcoholics.

In general, the research conducted by the subject is early adulthood and partly in late adolescents and students. Following the opinion of Havighurst (1972) put forward the tasks of early adult development: (1) choosing a life partner; (2) learn to live with a married partner; (3) starting a family life; (4) 
caring for children; (5) managing households; (6) start working; (7) responsible as citizens; and (8) finding matching social groups.

Marriage readiness is influenced by several factors, namely: emotional readiness, age readiness, social readiness, role readiness, sexual readiness, communication skills, spiritual readiness, and financial readiness (Goleman, 1997; Holman et al., 2015; Duval \& Miller, 1985; Blood, 1978). Besides the factors that influence marital readiness are emotional readiness (controlling emotions and empathy abilities), social (social skills, social cognition, and tolerance), roles, communication skills, age, financial, and sexual (Sari \& Sunarti, 2013).

The purpose of this study is to conduct a systematic study of the profile of marriage readiness of students based on different cultural backgrounds. Readiness will be seen based on aspects, based on gender and based on cultural background.

\section{METHOD}

This research uses a quantitative design of the analytic survey type. The survey research undertaken is included in the cross-sectional survey, which is a study to study the dynamics of correlation between cause and effect factors. The study was conducted on students with different cultural backgrounds using a marriage readiness scale that had been constructed based on Havighurst's developmental theory (1972). Scale using alternative answers yes and no with a score of one (1) and zero (0), respectively.

The survey was conducted based on two demographic backgrounds, namely: gender and cultural background. The cultural background of the participants can be grouped into two namely: 1) Malay, 2). Minangkabau. To find out the results of student marriage readiness, one-way Anova analysis was used. The $\mathrm{t}$ and ANOVA tests were used to help determine differences in marriage readiness between the sexes of men and women as well as to determine differences in the average marriage readiness based on the cultural background of students. 


\section{RESULTS AND DISCUSSION}

In general, student marriage readiness is in the high or ready category. Viewed by sex there is no significant difference between the sexes of men and women. More details can be seen in the following table:

Table. 1

Student Marriage Readiness

\begin{tabular}{ccccc}
\hline Gender & Culture & Mean & Std. Deviation & $\mathbf{N}$ \\
\hline \multirow{3}{*}{1,00} & 1,00 & 28,5833 & 3,55370 & 12 \\
\cline { 2 - 5 } & 2,00 & 32,0000 & 4,50925 & 7 \\
\cline { 2 - 5 } & Total & 29,8421 & 4,16684 & 19 \\
\hline \multirow{3}{*}{2,00} & 1,00 & 28,3125 & 3,55375 & 16 \\
\cline { 2 - 5 } & 2,00 & 31,8182 & 1,91824 & 22 \\
\cline { 2 - 5 } Total Difference & Total & 30,3421 & 3,20706 & 38 \\
\cline { 2 - 5 } & 1,00 & 28,4286 & 3,48997 & 28 \\
\cline { 2 - 5 } & 2,00 & 31,8621 & 2,66892 & 29 \\
\hline
\end{tabular}

Although the results of significance do not show the results of differences between the sexes of men and women. However, when viewed based on Cultural background, Malay culture students have lower scores than Minangkabau Culture students.

The results of this study differ from several studies that have been conducted in America. In America, several factors influence marriage readiness, namely: emotional readiness, age readiness, social readiness, role readiness, sexual readiness, communication skills, spiritual readiness, and financial readiness (Goleman, 1997; Holman et al., 2015; Duval \& Miller, 1985; Blood, 1978), emotions (controlling emotions and empathy abilities), social (social skills, social cognition, and tolerance), roles, communication skills, age, financial, and sexual (Sari \& Sunarti, 2013).

Research in America has not yet seen the influence of cultural background in marriage readiness. So the results of this study are new in the readiness of student marriages. Unlike in America, Indonesia studies have also been carried out to see what things affect marital readiness. Among them are age, gender and GPA, the number of siblings, age, number of illnesses suffered, cultural background and economic conditions (Oktaviani, 2010). Sari, et al (2016) also researched looking at marriage readiness factors, including Marital Life Skills, Financial readiness, Contextual-social readiness, Emotional Readiness, 
Interpersonal Readiness, Mental Readiness, Physical Readiness, Age Readiness.

Judging from the cultural factors, that students of Minangkabau culture are higher than Malay culture. This may have something to do with the readiness of marriage with individual independence. Where Minangkabau culture has high independence. This is due to the culture adopted by the Minangkabau people, they instill an independent attitude towards children from an early age with the adage that "where the earth is trampled down there on the road to visit" symbolizes where the child is located he can adjust so that the child's independence is formed by itself (Munir, 2013 ). So that if they are early adulthood, they can adjust to development tasks, especially for marriage readiness.

This does not mean that students of Malay culture do not have strong independence specifically about marital readiness, allowing other factors to cause the low readiness of Malay culture students' readiness. This is by the opinion of Santrock (2003) that many things affect independence one of which is culture.

The next step that can be taken to improve and develop marriage readiness is to conduct various training or interventions for students. Some forms of training and interventions that have been carried out are training education about marriage so that marital readiness can increase. Research on readiness for healthy marriage and relationship education training (Laura, Richardson, \& Cenizal, 2016). Other research that has been done also is an empirical approach to designing marriage preparation programs (Williams et al., 2010), Premarital Education, (Stanley, Amato, Johnson, \& Markman, 2006), Using Older Adults' Life Review (Magee, 2016).

\section{CONCLUSION}

Based on the results of the research, discussion and limitations obtained, the research process in the future can be directed to several demographic backgrounds related to parents (education, religion and beliefs, and economic level). This type of research can also be developed through survey studies with qualitative designs through in-depth interview-based data collection methods. The results showed that the readiness of marriage to students is an important thing to create happiness in marriage. Marriage readiness for each individual will be different. Differences can be seen from various demographic 
backgrounds inherent in individuals. The results of this study indicate that there is no significant difference between the readiness of marriage for male and female students. Meanwhile, Minangkabau's cultural background is known to have a high marriage readiness compared to Malay culture.

\section{REFERENCE}

Badger, S., \& Badger, S. (2005). Ready or Not? Perceptions of Marriage Readiness among Emerging Adults by.

Blood, M. B. (1978). Marriage ( $3^{\text {rd }}$ ed). New York, US: Free Press.

Carroll, J. S., Padilla-walker, L. M., Nelson, L. J., Olson, C. D., Barry, C. M., Madsen, S. D., ... Barry, C. M. (2008). Use Among Emerging Adults. https://doi.org/10.1177/0743558407306348.

Duvall, E. M., \& Miller, B. C. (1985). Marriage and family development $\left(9^{\text {th }}\right.$ ed). New York, US: Harper and Row Publisher.

Goleman, D. (1997). Kecerdasan emosional. Jakarta, ID: PT Gramedia Pustaka Utama. Terjemahan dari: Emotional Intelligence.

Gunnels, M. J. (2013). The Impact of Self-Esteem and Religiosity on the Marital Readiness Criteria of College Students.

Holman, T. B., \& Li, B. D. (1997). Premarital factors influencing perceived readiness for marriage. Journal of Family Issues, 18, 124-144.

Holman, T. B., Larson, J. H., Harmer, S. L., Holman, T. B., Larson, J. H., \& Harmer, S. L. (2015). The Development and Predictive Validity of a new Premarital Assessment Instrument the Preparation for Marriage Questionnaire *, 43(1), 46-52.

Larson, J. H. (1988). Factors influencing college students. perceived readiness for marriage. Family Perspective, 22, 145-156

Larson, J. H., \& Thayne, T. R. (n.d.). Alcoholism Treatment Quarterly Marital Attitudes and Personal Readiness for Marriage of Young Adult Children of Alcoholics, (November 2014), 37-41. https://doi.org/10.1300/J020v16n04

Laura, A., Richardson, E. W., \& Cenizal, R. (2016). Children and Youth 
Services Review Ready or not: The in $\mathrm{fl}$ uence of readiness on healthy marriage and relationship education training outcomes. Children and Youth Services Review, 63, 67-73. https://doi.org/10.1016/j.childyouth.2016.02.014

Magee, J. J. (2016). Using Older Adults $\hat{a} €^{\mathrm{TM}}$ Life Review in Marriage Preparation Using Older Adults ' Life Review in Marriage Preparation : Report from a Pilot Project, 4788(January). https://doi.org/10.1300/J016v29n02.

Miller, B. C., Schvaneveldt, J. D., \& Jenson, G. O. (1981). Reciprocity between family life research and education. Family Relations, 30, 625-630.

Munir, Misnal. (2013). Hidup di Rantau dengan Damai. Niali-nilai Kehidupan Orang Minangkabau dalam Menyesuaikan Diri dengan Lingkungan Budaya Baru. Prosiding The International Conference on Indonesian Studies: "Ethnicity and Globalization.

Oktaviani. Vivi. 2010. Faktor-Faktor yang Mempengaruhi Persepsi dan Kesiapan Menikah pada Mahasiswa (Kasus Mahasiswa Angkatan 2006 Institut Pertanian Bogor). Skripsi. Tidak diterbitkan. Departemen Ilmu Keluarga dan Konsumen, Fakultas Ekologi Manusia, Institut Pertanian Bogor.

Santrock, John W. (2003) Adolescence. Perkembangan Remaja. Edisi Keenam. Jakarta: Erlangga.

Sari, F., \& Sunarti, E. (2013). Usia Menikah Marriage Readiness among Young Adults and Its Influence on the Marriage Age Abstract, 6(3), 143-153.

Sari. Yunita, dkk. 2016. Studi mengenai Kesiapan Menikah pada Muslim Dewasa Muda. Prosiding Seminar Nasional Penelitian dan PKM Kesehatan. 6 (1) hal. 193-204.

Stanley, S. M., Amato, P. R., Johnson, C. A., \& Markman, H. J. (2006). Premarital Education, Marital Quality , and Marital Stability : Findings From a Large , Random Household Survey, 20(1), 117-126. https://doi.org/10.1037/0893-3200.20.1.117.

Stinnett, N. (1969). Readiness for marital competence. Journal of Home Economics, 61, 683-686

Williams, L. M., Riley, L. A., \& Dyke, D. T. Van. (2010). The American Journal of An empirical approach to designing marriage preparation programs, 
(June 2014), 37-41. https://doi.org/10.1080/019261899261970

Wilmoth, J. D., \& Smyser, S. L. (n.d.). Journal of Couple \& Relationship Therapy: Innovations in Clinical and Educational Interventions Use of Premarital Assessment Questionnaires by Clergy in Marriage Preparation, (November 2014), 37-41. https://doi.org/10.1080/15332691.2010.491783. 